\title{
CURRENT LITERATURE ON PERCEPTION, PERFORMANCE, AND EXPERIMENTAL SOCIAL PSYCHOLOGY
}

Citations of current literature are arranged in outline form so that readers may easily find the particular articles in which they are interested. The literature on Human Experimental Psychology is divided into two parts, with each part appearing in alternate months. The part covered here consists of Perception. Performance. and Experimental Social Psychology. The part to be published next month will consist of citations on Human Memory, Learning, and Thinking. The principal headings used are given on the cover along with page references.

\section{TECHNIQUES}

\section{METHODS}

CLIFTON, R. K. (Univ. of Massachusetts, Amherst, Mass. 01002 ), MEYERS, W. J., \& SOLOMONS, M. D. Methodological problems in conditioning the headturning response of newborn infants. Journal of Experimental Child Psychology, 1972, 13, 29-42.

DeCASPER, A. J. (Emory Univ., Atlanta, Ga. 30322), \& ZEILER, M. D. Steady-state behavior in children: A method and some data. Journal of Experimental Child Psychology, 1972, 13, 231-239.

HIRATA, K. (Univ. of Waterloo, Waterloo, Ont., Canada), \& BRYDEN, M. P. Tables of letter sequences varying in order of approximation to English. Psychonomic Science, 1971, 25, 322-324.

MUELLER, D. J. (Univ. of Wisconsin-Milwaukee, Milwaukee, Wis. 53201), \& GUMINA, J. M. Methodological studies involving reward and punishment in human learning: I. Effects of design and instructions. Perceptual \& Motor Skills, 1972, 34, 63-74.

SALVIA, J. A. (Univ. of Illinois, Urbana, Ill.61801), \& YSSELDYKE, J. E. Validity and reliability of the red-green $A O$ H-R-R pseudoisochromatic plates with mentally retarded children. Perceptual \& Motor Skills, 1971, 33, 1071-1074.

VERPLANCK, W. S. (Univ. of Tennessee, Knoxville, Tenn. 37916). Further overstatements of a phenomenological behaviorist. Psychological Record, 1971, 21, 481-486.

WEIMER, W. B. (Pennsylvania State Univ., University Park, Pa. 16802). The methodology of scientific research in psychology: A comment on Verplanck. Psychological Record, 1971, 21, 471-480.

\section{INSTRUMENTATION}

RAY, W. S. (Bethany Coll., Bethany, W. Va. 26032). A Skinner Box recorder for the blind student.
Psychological Record, 1971, 21, 527.

STEIN, B. E. (Dept. of Anatomy, Med. Ctr., Sch. of Med., Univ. of California, Los Angeles, Calif. 90024), DODICH, N., \& KRUGER, L. A stimulus apparatus for the presentation of moving visual stimuli. Vision Research, 1972, 12, 333-336.

\section{STATISTICAL TECHNIQUES}

ALF, E. F., \& ABRAHAMS, N. M. (Nav. Pers. \& Trng. Sch. Lab., Dept. of the Navy, San Diego, Calif. 92152 ). Comment on component-randomization tests. Psychological Bulletin, 1972, 77, 223-224.

BEAVER, R. J. (Univ. of California, Riverside, Calif. 92501), \& RAO, P. $V$. The use of limit theorems in paired and triple comparison model building. Journal of Mathematical Psychology, 1972, 9, 92-103.

FALMAGNE, J. C. (New York Univ., 707 Broadway, New York, N.Y. $10003)$. Bounded versions of Hölder's Theorem with application to extensive measurement. Journal of Mathematical Psychology, 1971, 8, 495-507.

FLEISS, J. L. (Biometrics Rsch., New York State Dept. of Mental Hygiene, 722 W. 168 St., New York, N.Y. 10032). Measuring nominal scale agreement among many raters. Psychological Bulletin, 1971, 76, 378-382.

GREY, D. R. (Trinity Coll., Oxford, England), \& MORGAN, B. J. T. Some aspects of ROC curve-fitting: Normal and logistic models. Journal of Mathematical Psychology, 1972, $9,128-139$.

HOLMAN, E. W. (Univ. of California, Los Angeles, Calif. 90024). A note on additive conjoint measurement. Journal of Mathematical Psychology, 1971, 8, 489-494.

LEVINE, M. V. (Univ, of Pennsylvania, Philadelphia, $\mathrm{Pa}$. 19104). Transforming curves into curves with the same shape. Journal of Mathematical Psychology, 1972, 9, 1-16.

MEEHL, P. E. (Psychiat. Rsch. Unit, Box 392 Mayo, Univ. of Minnesota, Minneapolis, Minn. 55455), LYKKEN, D. T., SCHOFIELD, W., \& TELLEGEN, A. Recaptured-item technique (RIT): A method for reducing somewhat the subjective element in factor naming. Journal of Experimental Research in Personality, 1971, 5, 171-190.

NAKATANI, L. H. (Bell Tel. Lab., Inc., Murray Hill, N.J. 07974). Confusion-choice model for multidimensional psychophysics. Journal of Mathematical Psychology, 1972, 9, 104-127.

NAMBOODIRI, N. K. (Dept. of Sociology, Univ. of North Carolina, Chapel Hill, N.C. 27514). Experimental designs in which each subject is used repeatedly. Psychological Bulletin, 1972, 77, 54-64.

RIMOLDI, H. J. A. (Loyola Univ., Chicago, Ill. 60626), DONNELLY, M. B., \& LAACK, W. J. Anchoring effects in psychological scaling. American Journal of Psychology, 1971, 84, 407-420.

ROECKELEIN, J. E. (Mesa Coll., Mesa, Ariz. 85201). Failure to make orthogonal polynomial adjustments for unequally spaced intervals yields inaccurate $F$ values in trend tests. Perceptual \& Motor Skills, 1971, $33,1179-1183$.

SHAFFER, J. P. (Univ. of Kansas, Lawrence, Kans. 66044). Directional statistical hypotheses and comparisons among means. Psychological Bulletin, 1972, 77, 195-197.

WAGENAAR, W. A. (Inst. for Perception RVO-TNO, Kampweg 5, Soesterberg, Postbus 23, The Netherlands). Generation of random sequences by human subjects: A critical survey of literature. Psychological Bulletin, 1972, 77, 65-72.

\section{COMPUTER TECHNOLOGY}

AIKIN, J. O. (Brown Univ., Providence, R.I. 02912), \& MILLWARD, R. B. Some comments on connecting a small on-line computer to a large data processing 
machine. Behavior Research Methods \& Instrumentation, 1972, 4, 99-100.

ARMINGTON, J. C. (Northeastern Univ., Boston, Mass. 02115). Using the Lab-8 for experimentation with the human visual system. Behavior $\mathrm{R}$ es e a c h M e thods \& Instrumentation, 1972, 4, 61-63.

BAILEY, D. E. (Univ. of Colorado, CLIPR, 1511 University Ave., Boulder, Colo. 80302). The computer laboratory for instruction in psychological research, CLIPR. Behavior Research Methods \& Instrumentation, 1972, 4, 95-96.

CARTERETTE, E. C. (Univ. of California, Los Angeles, Calif. 90024), BARNEBEY, A., LOVELL, J. D., NAGEL, D. C., \& FRIEDMAN, M. P. On-line computing with the Hewlett-P a ckard $2116 \mathrm{~B}$ moving-head disk operating system. Behavior Research Methods \& Instrumentation, 1972, 4, 89-94.

CHAPMAN, R. M. (Eye Rsch. Fdtn. of Bethesda, Bethesda, Md. 20014), \& CHAPMAN, J. A. The General Automation $18 / 30$ as a system for the general analysis and acquisition of data in physiological psychology. Behavior Research Methods \& Instrumentation, 1972, 4, 77-81.

CONNOLLY, J. A. (American Insts. for Rsrch., 8555 Sixteenth St., Silver Spring, Md. 20910), \& L A M B E R T, T. F. Computer-managed instruction: IBM System 360. Behavior Research Methods \& Instrumentation, 1972, 4, 85-88.

DOLL, T. J. (SUNY, Stony Brook, N.Y. 11790). A 4-K computer language for experimentation with human subjects. Behavior Research Methods \& Instumentation, 1972, 4, 27-31.

EAVES, L. J. (Dept. of Genetics, Univ. of Birmingham, P.O. Box 363 , Birmingh am 15, England). Computer simulation of sample size and experimental design in human psychogenetics. Psychological Bulletin, 1972, 77, 144-152.

ELLEN, P. (Georgic. State Univ., Atlanta, Ga. 30303), DeLOACHE, C. H., \& BONDS, J. Time-shared control of a variety of psychological laboratories using the IBM 1800 data acquisition and control computer. Behavior Research Methods \& Instrumentation, 1972, $4,81-85$.

GOODE, F. M. (Univ. of Michigan, Ann Arbor, Mich. 48104). Training mathematical psychology students in the use of a laboratory computer. Behavior Research Methods \& Instrumentation, 1972, 4, 96-97.

GREEN, B. F., JR. (Johns Hopkins Univ., Baltimore, Md. 21218). The use of time-shared terminals in

psychology. Behavior Research Methods \& Instrumentation, 1972, 4, 51-55.

HALASZ, M. F (Univ. of Manitoba, Winnipeg, Man., Canada). Operant behavior as an optimally controlled process. Behavior Research Methods \& Instrumentation, 1972, 4, 112-113.

LIVINGSTON, J. W., JR. (Rutgers Univ., New Brunswick, N.J. 08903). Measuring cooperation and competition in decomposed games. Behavior Research Methods \& Instrumentation, 1972, 4, 113-114.

MURDOCK, B. B. (Univ. of Toronto, Toronto, Ont., Canada), DUFTY, P. O., \& OKADA, R. Using the PDP-12 in verbal learning and short-term memory research. Behavior Research Methods \& Instrumentation, 1972, 4, 70-71.

POLSON, P. G. (CLIPR, 1511 University Ave., Room 4, Univ. of Colorado, Boulder, Colo. 80302). A brief description of EXTENDED SCAT. Behavior Research Methods \& Instrumentation, 1972, 4, 104-105.

RAHIMI, M. A. (Dept. of Computer Science, Michigan State Univ., East Lansing, Mich. 48822), \& FINO, T. A. The PLANIT computer-assisted instructional language: A potential tool of research in psychology. Behavior Research Methods \& Instrumentation, 1972, 4, 109-111.

RODEWALD, H. K. (Central Michigan Univ., Mt. Pleasant, Mich. 48858). PDP-8/LVE INTERACT system in an undergraduate environment. Behavior Research Methods \& Instrumentation, 1972, 4, 73-76

SIDOWSKI, J. B. (Univ. of South Florida, Tampa, Fla. 33620). Various uses of minicomputers in psychology. Behavior Research Methods \& Instrumentation, 1972, $4,43-50$.

SIEGEL, W. (Univ. of Western Ontario, London, Ont., Canada). Combining FOCAL and Assembly

\section{PERCEPTUAL AND SENSORY PROCESSES}

HASLAM, D. R. (Univ. of Bristol, Bristol, England). Field dependence in relation to pain threshold. British Journal of Psychology, 1972, 63, 85-87.

IRVING, A. (Road Rsch. Lab., Crowthome, Berkshire, England). Measurement of time indifference intervals. Perceptual \& Motor Skills, 1972, 34, 331-337.

KEENAN, V. (Univ. of Colorado, Boulder, Colo. 80302). Effects of Hebrew and English letters on children's perceptual set. Journal of Ex perimental Child Psychology, 1972, 13, 71-84. language. Behavior Research Methods \& Instrumentation, 1972, 4, 105-106.

TAYLOR, R. L. (Memorial Univ. of Newfoundland, St. John's, Nfld., Canada). COGLAB: A computer system designed for human research. Behavior Research Methods \& Instrumentation, 1972, 4, 94-95.

UTTAL, W. R. (Univ. of Michigan, Ann Arbor, Mich. 48104). Misuse, abuse, overuse, and unuse of on-line computer facilities by psychologists. Behavior Research Methods \& Instrumentation, 1972, 4, 55-60.

VAN,GELDER, P. (Univ. of Connecticut, Storrs, Conn. 06268). CRT displays in the experimental psychology laboratory. Behavior $\mathrm{R}$ e s e a r h M e thods \& Instrumentation, 1972, 4, 102-103.

WALLSTEN, T. S. (L. L. Thurstone Psychometric Lab., Univ. of North Carolina, Chapel Hill, N.C. 27514). 8TRAN language and the PDP-8 facility at the L. L. Thurstone Psychometric Laboratory. Behavior Research Methods \& Instrumentation, 1972, 4, 107-108.

WHITMORE, D. G. (Univ. of Vermont, Burlington, Vt. 05401), \& GORDON, L. R. Toward the on-line analysis of raw bioelectric signals: The case of EEG. Behavior Research Methods \& Instrumentation, 1972, $4,98$.

WICKENS, T. D., HOWARD, J., RICE, G., \& MILLWARD, R. B. (Brown Univ., Providence, R.I. 02912). GASPS: A General ASynchronous Processing System for the PDP-8. Behavior Research Methods \& Instrumentation, 1972, 4, 108-109.

YOUNG, J. L. (SUNY, Stony Brook, N.Y. 11790). AVALA. a small on-line system with off-line communication with a large computer. Behavior Research Methods \& Instrumentation, 1972, $4,100-101$.

ODOM, R. D. (Vanderbilt Univ., Nashville, Tenn. 37203). Effects of perceptual salience on the recall of relevant and incidental dimensional values: A developmental study. Journal of Experimental Psychology, 1972, 92, 285-291.

SHUGART, B. J. (Le Tourneau Coll., Longview, Tex. 75601), SOUDER, M. A., \& BUNKER, L. K. Relationship between vertical space perception and a dynamic non-locomotor balance task. Perceptual \& Motor Skills, 1972, 34, 43-46.

VAUGHT, G. M. (SUNY, Oswego, N.Y. 13126). Accounting for sex 
differences on the rod-and-frame test. Perceptual \& Motor Skills, $1971,33,1114$.

\section{Psychophysics}

CRAIG, J. C. (Indiana Univ., Bloomington, Ind. 47401). Difference threshold for intensity of tactile stimuli. Perception \& Psychophysics, 1972, 11, 150-152.

FIORENTINI, A. (Laboratorio di Neurofisiologia del CNR, Pisa Italy), BAYLY, E. J., \& MAFFEI, L. Peripheral and central contributions to psychophysical spatial interactions. Vision Research, 1972, 12, 253-259.

FUCCI, D. J. (Ohio Univ., Athens, Ohio 45701), HALL, D. E., \& WEINER, F. F. Normative study of oral and non-oral structures using vibrotactile stimuli. Perceptual \& Motor Skills, 1971, 33, 1099-1105.

GRANBERG D. (Dept. of Sociology, Univ. of Missouri, Columbia, Mo. 65201 ). Adaptation of psychophysical and psychosocial judgments to shifts in stimuli. Journal of General Psychology, $1972,86,85-92$.

HIESEY, R. W. (Stanford Univ., Stanford, Calif. 94305), \& SCHUBERT, E. D. Cochlear resonance and phase-reversed signals. Journal of the Acoustical Society of America, 1972, 51, 518-519.

LUCE, R. D., \& GREEN, D. M. (Univ. of California, San Diego, La Jolla, Calif. 92037). A neural timing theory for response times and the psychophysics of intensity. Psychological Review, 1972, 79, 14-57.

McGUIGAN, F. J. (Hollins Coll., Hollins College, Pa. 24020), \& PA VEK, G. V. On the psychophysiological identification of covert nonoral language processes. Journal of Experimental Psychology, 1972, 92, 237-245.

MOSKOWITZ, H. R. (Pioneering Rsch. Lab., U.S. Army Natick Labs., Natick, Mass. 01760). The sweetness and pleasantness of sugars. American Journal of Psychology, 1971, 84, 387-406.

NAKATANI, L. H. (Bell Tel. Labs., Murray Hill, N.J. 07974). Confusion-choice model for multidimensional psychophysics. Journal of Mathematical Psychology, 1972, 9, 104-127.

TEGHTSOONIAN, R. (Smith Coll., Northampton, Mass. 01060), \& TEGHTSOONIAN, M. The apparent lengths of perimeters and diameters define a ratio smaller than pi. American Journal of Psychology, $1971,84,437-438$.

VOLKMANN F. C. (Clark Sci. Ctr., Smith Coll., Northampton, Mass.
01060), \& PUFALL, P. B. Adjustments of visual tilt as a function of age. Perception \& Psychophysics, 1972, 11, 187-192.

\section{Aftereffects}

BYTH, W. (Queen's Univ. of Belfast, Belfast, Northern Ireland), \& PEARN, L. Visual illusion and figural aftereffect in relation to field dependence. Psychonomic Science, 1972, 26, 204-206.

MEHLING, K. D. (Psychol. Lab., Civil Aeromed. Inst., FAA, Oklahoma City, Okla. 73100), COLLINS, W. E., \& SCHROEDER, D. J. Some effects of perceived size, retinal size, and retinal speed on duration of spiral aftereffect. Perceptual \& Motor Skills, 1972, 34, 247-259.

MONTGOMERY, N. (Univ. of Southern Mississippi, Hattiesburg, Miss. 39401). Effects of distance and retinal velocity on duration of spiral aftereffect. Perceptual \& Motor Skills, 1971, 33, 1239-1244.

\section{Illusions}

BYTH, W. (Queen's Univ. of Belfast, Belfast, Northern Ireland), \& PEARN, L. Visual illusion and figural aftereffect in relation to field dependence. Psychonomic Science, 1972, 26, 204-206.

DAVIS, C. M. (Syracuse Univ., Syracuse, N.Y. 13210), \& SEGALL, M. H. Effect of relative positions of segments on strength of the Mueller-Lyer illusion. Perceptual \& Motor Skills, 1971, 33, 1051-1058.

EBERT, P. C. (Univ. of Georgia, Athens, Ga. 30601), \& POLLACK, R. H. Magnitude of the Mueller-Lyer illusion as a function of hue, saturation, and fundus pigmentation. Psychonomic Science, 1972, 26, 225-226.

EFRON, R. (VA Hosp., Martinez, Calif. 94553), \& LEE, D. N. The visual persistence of a moving stroboscopically illuminated object. American Journal of Psychology, $1971,84,365-377$

ELLIS, H. (Univ. of Aberdeen, Aberdeen, Scotland), \& DEREGOWSKI, J. Note on methods used to determine magnitudes of geometrical illusions. Perceptual \& Motor Skills, 1972, 34,50 .

GOODWIN, G. M. (Univ. Lab. of Physiol., Oxford, OX1 3PT England), McCLOSKEY, D. I., \& M A T T H E S , P. B C. Proprioceptive illusions induced by muscle vibration: Contribution by muscle spindles to perception? Science, 1972, 175, 1382-1384.

HILL, A. L. (Inst. for Basic Rsch. in Mental Retardation, Staten Island, N.Y. 10314). On the enlargement of acute angles. Perceptual \& Motor
Skills, 1971, 33, 1238

MATHENY, A. P., JR. (Child Dev. Unit, Pediatrics Dept., Univ, of Louisville Sch. of Med., Health Sci. Ctr., Louisville, Ky. 40201), \& BROWN, A. M. Personality factors associated with the Ponzo illusion: Study using the co-twin method. Perceptual \& Motor Skills, 1972, 34, 119-124.

TAYAL, O. P. (Indian Inst. of Tech., Kanpur, India). Visual processing: General principles for an interpretation of geometric illusions. Journal of General Psychology, 1972, 86, 93-115.

\section{Signal Detection}

PASTORE, R. E. (Purdue Univ. Lafayette, Ind. 47907), \& SORKIN, R. D. Simultaneous two-channel signal detection. I. Simple binaural stimuli. Journal of the Acoustical Society of America, 1972, 51, 544-551.

PENNER, M. J. (Univ. of California, San Diego, La Jolla, Calif. 92037). The effect of payoffs and cue tones on detection of sinusoids of uncertain frequency. Perception \& Psychophysics, 1972, 11, 198-202.

R APPAPORT, M. (Agnews State Hosp., San Jose, Calif. 95114), HOPKINS, H. K., SILVERMAN, J., \& HALL, K. Auditory signal detection in schizophrenics. Psychopharmacologia (Berlin), 1972, 24, 6-28.

\section{VISION}

ARMINGTON, J. C. (Northeastern Univ., Boston, Mass. 02115). Using the Lab-8 for experimentation with the human visual system. Behavior $\mathrm{R}$ esearch $\mathrm{M}$ e thods \& Instrumentation, 1972, 4, 61-63.

BYTH, W. (Queen s Univ. of Belfast, Belfast, Northern Ireland), \& PEARN, L. Visual illusion and figural aftereffect in relation to field dependence. Psychonomic Science, 1972, 26, 204-206.

COLTHEART, M. (Univ. of Waterloo, Waterloo, Ont., Canada), \& ARTHUR, B. Tachistoscopic hemifield effects with hemifield report. American Journal of Psychology, 1971, 84, 355-364.

DEMBER, W. N. (Univ. of Cincinnati, Cincinnati, Ohio 45221), \& STEFL, M. Backward enhancement? Science, 1972, 175, 93-95.

GELDARD, F. A. (Princeton Univ., Princeton, N.J. 08540). Vision-from a wide mantel. Perception \& Psychophysics, 1972, 11, 193-197.

PANGMAN, C. H. (Univ. of Manitoba, Winnipeg, Man., Canada), \& ZUBEK, J. P. Changes in auditory flutter fusion frequency during prolonged visual deprivation. 
Perception \& Psychophysics, 1972, 11, 172-174.

TAYAL, O. P. (Indian Inst. of Tech., Kanpur, India). Visual processing: General principles for an interpretation of geometric illusions. Journal of General Psychology, 1972, 86, 93-115.

\section{Visual Sensitivity}

ALGVERE, P. (Dept. of Ophthal., Karolinska Hospital, Stockholm 60, Sweden), \& WESTBECK, S. Human ERG in response to double flashes of light during the course of dark adaptation: A Fourier analysis of the oscillatory potentials. Vision Research, 1972, 12, 195-214.

BARRY, R. J. (Univ. of Sydney, Sydney, 2006, N.S.W., Australia), \& $\mathrm{BEH}, \mathrm{H}$. C. Desynchronization of the alpha rhythm of the EEG as a function of intensity of visual stimulation. Psychonomic Science, $1972,26,241-242$.

BROWN, B. Dept. of Ophthalmic Optics \& Vis. Sci., City Univ., London EC1V 4PB, England). Resolution thresholds for moving targets at the fovea and in the peripheral retina. Vision Research, 1972, 12, 293-304.

FIORENTINI, A. (Laboratorio di Ne urofisiologia del CNR, Pisa, Italy), BAYLY, E. J., \& MAFFEI, L. Peripheral and central contributions to psychophysical spatial interactions. Vision Research, 1972, 12, 253-259.

GLAD, A. (Sec. of Sensory Psychol. \& Psychophysiol., Inst. of Psychol., Univ. of Oslo, Norway), \& MAGNUSSEN, S. Darkness enhancement in intermittent light: An experimental demonstration. Vision Research, 1972, 12, 111-115.

KELLY, D. H. (Stanford Rsch. Inst., Menlo Park, Calif. 94025). Adaptation effects on spatio-temporal sine-wave thresholds. Vision Research, 1972, 12, 89-101.

OHZU, H., \& ENOCH, J. M. (Dept. of Ophthal., Washington Univ. Sch. of Med., 660 S. Euclid Ave., St. Louis, Mo. 63110). Optical modulation by the isolated human fovea. Vision Research, 1972, 12, 245-251.

ROUFS, J. A. J. (Institut voor Perceptic Onderzoek, Insulindelaan 2, Eindhoven, The Netherlands). Dynamic properties of vision-I. Experimental relationships between flicker and flash thresholds. Vision Research, 1972, 12, 261-278.

ROUFS, J. A. J. (Institut voor Perceptic Onderzoek, Insulindelaan 2, Eindhoven, The Netherlands). Dynamic properties of vision-II. Theoretical relationships between flicker and flash thresholds. Vision
Research, 1972, 12, 279-292.

STANLEY, G. (Univ. of Melbourne, Parkville, Victoria, Australia), \& FROWEIN, H. Apparent brightness of gapped and non-gapped moving lines. Perceptual \& Motor Skills, 1971, 33, 1175-1177.

\section{Spatial Vision}

BARTHOLOMEUS, B. (Sch. of Human Communication Disorders, McGill Univ., Montreal 112, P.Q., Canada). Naming of meaningful nonverbal sounds by blind children. Perceptual \& Motor Skills, 1971, 33, 1289-1290.

BRAVEMAN, N. S. (Memorial Univ. of Newfoundland, St. John's, Nfld., Canada), \& KATZ, L. Spatial and visual probability learning in the kinkajou. Perceptual \& Motor Skills, $1971,33,1115-1121$.

COLLINS, J. K. (Macquarie Univ., North Ryde, N.S.W. 2113, Australia). Subjective velocity estimates of apparent movement following visual stimulation. Perceptual \& Motor Skills, 1971, 33, 1029-1030.

EFRON, R. (VA Hosp., Martinez, Calif. 94553), \& LEE, D. N. The visual persistence of a moving stroboscopically illuminated object. American Journal of Psychology, 1971, 84, 365-377.

EPSTEIN, W. (Univ. of Wisconsin, Madison, Wis. 53706). Retention of adaptation to uniocular image magnification: Effect of interpolated activity. Journal of Experimental Psychology, 1972, 92, 319-324.

ERKE, H. (Institut für Psychologie, Abteilung für angewandte Psychologie, 3300 Braunschweig, Technische Universität, Postfach 7050), \& GRÄSER, H. Reversibility of perceived motion: Selective adaptation of the human visual system to speed, size and orientation. Vision Research, 1972, 12, 69-87.

FOLEY, J. M. (Univ. of California, Santa Barbara, Calif. 93106). The size-distance relation and intrinsic geometry of visual space: Implications for processing. Vision Research, 1972, 12, 323-332.

F REEMAN, R. D. (Sch. of Optometry, Univ. of California, Berkeley, Calif. 94720 ), MITCHELL, D. E., \& MILLODOT M. A neural effect of partial visual deprivation in humans. Science, $1972,175,1384-1386$.

GILINSKY, A. S. (Physiol. Lab., Cambridge CB2 3EG, England), \& COHEN, H. H. Reaction time to change in visual orientation. Perception \& Psychophysics, 1972, 11, 129-134.

GIPS, J. (Computer Sci. Dept.,
Stanford Univ, Stanford, Calif. 94305). A new reversible figure. Perceptual \& Motor Skills, 1972, $34,306$.

GOGEL, W. C. (Univ. of California, Santa Barbara, Calif. 93106), \& STURM, R. D. A comparison of accommodative and fusional convergence as cues to distance. Perception \& Psychophysics, 1972, 11, 166-168.

GUMMERMAN, K. (Mezes Hall 211, Univ. of Texas, Austin, Tex. 78712), \& GRAY, C. R. Age, iconic storage, and visual information processing. Journal of Experimental Child Psychology, 1972, 13, 165-170.

HILL, A. L. (Inst. for Basic Rsch. in Mental Retardation, 1050 Forest Hill Rd., Staten Island, N.Y. 10314). Direction constancy. Perception \& Psychophysics, 1972, $11,175-178$

HUGHES, P. C. (Dept. of Psychiat. \& Behav. Sci., Univ. of Oklahoma Med. Ctr., 800 N.E. 13th St., Oklahoma City, Okla. 73104), BRECHER, G. A., \& FISHKIN, S. M. Effects of rotating backgrounds upon the perception of verticality. Perception \& Psychophysics, 1972, 11, 135-138.

KESSEN, W. (Yale Univ., New Haven, Conn. 06520), SALAPATEK, P., \& HAITH, M. The visual response of the human newborn to linear contour. Journal of Experimental Child Psychology, 1972, 13, 9-20.

LAWSON, R. B. (John Dewey Hall, Univ. of Vermont, Burlington, Vt. 05401), GULICK, W. L., \& PARK, M. Stereoscopic size-distance relationships from line-drawn and dot-matrix stereograms. Journal of Experimental Psychology, 1972, 92, 69-74.

MILLER, L. K. (Univ, of Illinois, Chicago Circle, Chicago, Ill. 60680). Letter recognition: Effects of interitem similarity and report requirements. Perception \& Psychophysics, 1972, 11, 252-256.

RICHARDS, L. G. (Univ. of Virginia, Charlottesville, Va. 22901). An analysis of individual differences in similarity judgments about complex random forms. Perception \& Psychophysics, 1972, 11, 143-149.

SMITH, E. E. (Stanford Univ., Stanford, Calif. 94305), \& HAVILAND, S. E. Why words are perceived more accurately than nonwords: Inference versus unitization. Journal of Experimental Psychology, 1972, 92, 59-64.

SNYDER, C. R. R. (Univ. of Oregon, Eugene, Oreg. 97403). Selection, inspection, and naming in visual search. Journal of Experimental Psychology, 1972, 92, 428-431. 
STACEY, B. G. (Univ, of Strathclyde, Glasgow, C. 1, Scotland), \& MACLEAN, I. E. Scalar perception and judgment of angles. Perceptual \& Motor Skills, 1972, 34, 295-298.

TAYLOR, J. G. (110 Freedom Ave., Riverside, Kitwe, Zambia). Underwater distortion: And plain distortion. British Journal of Psychology, 1972, 63, 31-40.

VOLKMANN, F. C. (Clark Sci. Ctr., Smith Coll., Northampton, Mass. 01060), \& PUFALL, P. B. Adjustments of visual tilt as a function of age. Perception \& Psychophysics, 1972, 11, 187-192.

WALKER, J. T. (Univ. of Missouri, St. Louis, Mo. 63121). Natural visual capture in bilateral length comparisons. Perception \& Psychophysics, 1972, 11, 247-251.

WALLACH, H. (Swarthmore Coll., Swarthmore, Pa. 19081), \& FREY, K. J. On counteradaptation. Perception \& Psychophysics, 1972, 11, 161-165.

\section{Color Vision}

BERNSTEIN, I. H. (Univ. of Texas, Arlington, Tex. 76010), EASON, T. R., \& SCHURMAN, D. L. Hue-tone sensory interaction: A negative result. Perceptual \& Motor Skills, $1971,33,1327 \cdot 1330$.

HOPSON, J. (Texas Tech Univ., Lubbock, Tex. 79409), COGAN, R., \& BATSON, C. Color preference as a function of background and illumination. Perceptual \& Motor Skills, 1971, 33, 1083-1088.

YOUNG, R. H. (Ripon Coll., Ripon, Wis. 54971), \& LIT, A. Stereoscopic acuity for photometrically matched background wavelengths at scotopic and photopic levels. Perception \& Psychophysics, 1972, 11, 213-216.

\section{Eye Movements}

BROWN, B. (Dept. of Ophthalmic Optics \& Vis. Sci., City Univ., London EC1 V4PB, England). Dynamic visual acuity, eye movements and peripheral acuity for moving targets. Vision Research, $1972,12,305-321$.

CHASE, R. (Dept. of Biol., McGill Univ., Montreal 110, P.Q., Canada), \& KALIL, R. E. Suppression of visual evoked responses to flashes and pattern shifts during voluntary saccades. Vision Research, 1972, $12,215-220$.

FEINSTEIN, R. (Marine Biomed. Inst., 200 University Blvd., Galveston, Tex. 77550), \& WILLIAMS, W. J. Interactions of the horizontal and vertical human oculomotor systems: The saccadic systems. Vision Research, 1972, 12, 33-44.

FEINSTEIN, R. (Marine Biomed. Inst., 200 University Blvd.,
Galveston, Tex. 77550), \& WILLIAMS, W. J. Interactions of the horizontal and vertical human oculomotor systems: The vertical smooth pursuit and horizontal saccadic systems. Vision Research, $1972,12,45-52$.

HINTON, J. W. (Univ. of Southampton, Southampton, England). Autokinesis and eye movement control-system stabilization: Pilot study on effect of brief hand viewing. Perceptual \& Motor Skills, 1972, 34, 330.

OSCAR-BERMAN, M. (Psychol. Service, Boston VA Hosp., $150 \mathrm{~S}$. Huntington Ave., Boston, Mass. 02130), \& BAKOPLUS-BANOS, J. Eye orientation during visual discrimination learning by humans. Perceptual \& Motor Skills, 1971, 33, 1311-1316.

SKAVENSKI, A. A. (Traylor Rsch. Bldg., Rm. 830, Dept. of Biomed. Eng., Johns Hopkins Univ. Med. Sch., Baltimore, Md. 21205). Inflow as a source of extraretinal eye position information. Vision Research, 1972, 12, 221-229.

\section{AUDITION}

BENSON. D. A. (Univ. of Florida, Gainesville, Fla. 32601), \& TEAS, D. C. Human auditory-evoked response: Specific effects of signal strength and performance criterion. Perception \& Psychophysics, 1972, 11, 203-208.

BERNSTEIN, I. H. (Univ. of Texas, Arlington, Tex. 76010), EASON, T. R., \& SCHURMAN, D. L. Hue-tone sensory interaction: A negative result. Perceptual \& Motor Skills, $1971,33,1327-1330$.

BRIGGS, R. M., \& PERROTT, D. R (California State Coll., Los Angeles, Calif. 90032). Auditory apparent movement under dichotic listening conditions. Journal of Experimental Psychology, 1972, 92, 83-91.

COHEN, A. (Natl. Inst. for Occupational Safety \& Health, PHS, U.S. Dept. of HEW, 1014 Broadway, Cincinnati, Ohio 45202), A N T I CA G L IA, J . R ., \& CARPENTER, P. L. Temporary threshold shift in hearing from exposure to different noise spectra at equal $\mathrm{dB} A$ level. Journal of the Acoustical Society of America, 1972, 51, 503-507.

CRANE, H. D. (Stanford Rsch. Inst., Menlo Park, Calif. 94025). Mechanical impact and fatigue in relation to nonlinear combination tones in the cochlea. Journal of the Acoustical Society of America, $1972,51,508-514$.

HELLER, M. A. (Yeshiva Univ., New York, N.Y. 10003), \& AUERBACH C. Practice effects in the absolute judgment of frequency.
Psychonomic Science, 1972, 26, 222-224.

HELLMAN, R. P. (Harvard Univ., Cambridge, Mass. 02138). Asymmetry of masking between noise and tone. Perception \& Psychophysics, 1972, 11, 241-246. HIESEY, R. W. (Stanford Univ., Stanford, Calif. 94305), \& SCHUBERT, E. D. Cochlear resonance and phase-reversed signals. Journal of the Acoustical Society of America, 1972, 51, 518-519.

MATSUMIYA, Y. (Dept. of Neurol., Children's Hosp. Med. Ctr., Boston, Mass. 02115), TAGLIASCO, V., L O M B O S O, C. T., \& GOODGLASS, H. Auditory evoked response: Meaningfulness of stimuli and interhemispheric asymmetry. Science, 1972, 175, 790-792.

McFADDEN, D. TUniv. of Texas, Austin, Tex. 78712), RUSSELL, W. E., \& PULLIAM, K. A. Monaural and binaural masking patterns for a low-frequency tone. Journal of the Acoustical Society of America, $1972,51,534-543$.

MIKAELIAN, H. H. (Connecticut Coll., New London, Conn. 06320). Lack of bilateral generalization of adaptation to auditory rearrangement. Perception \& Psychophysics, 1972, 11, 222-224.

PANGMAN, C. H. (Univ of Manitoba, Winnipeg, Man., Canada), \& ZUBEK, J. P. Changes in auditory flutter fusion frequency during prolonged visual deprivation. Perception \& Psychophysics, 1972 . 11, 172-174.

PREUSSER, D. (Dunlap \& Associates, 1 Parkland Dr., Darien, Conn. 06820). The effect of structure and rate on the recognition and description of auditory temporal patterns. Perception \& Psychophysics, 1972, 11, 233-240.

PRICE, G. R. (Human Eng. Labs., U.S. Army R \& D Ctr., Aberdeen Proving Ground, Md. 21005). Functional changes in the ear produced by high-intensity sound. II. $500-\mathrm{Hz}$ stimulation. Journal of the Acoustical Society of America, $1972,51,552-558$.

STOKINGER, T. E. (VA Hosp., Oklahoma City, Okla. 73104), COOPER, W. A., JR., \& MEISSNER, $W$. A. Influence of binaural interaction on the measurement of perstimulatory loudness adaptation. Journal of the Acoustical Society of America, $1972,51,602-607$.

STOKINGER, T. E. (VA Hosp., Oklahoma City, Okla. 73104), COOPER, W. A., JR., MEISSNER, W. A., \& JONES, K. O. Intensity, frequency, and duration effects in the measurement of monaural 
perstimulatory loudness adaptation. Journal of the Acoustical Society of America, 1972, 51, 608-616.

TEPAS, D. I. (St. Louis Univ., $221 \mathrm{~N}$. Grand Blvd., St. Louis, Mo. 63103), BOXERMAN, L. A., \& ANCH A. $M$. Auditory evoked brain responses: Intensity functions from bipolar human scalp recordings. Perception \& Psychophysics, 1972, 11, 217-221.

TIMMONS, B. A. (Univ. of Victoria, Toronto, Ont., Canada). Expectancy as a factor in reaction to delayed auditory feedback. Perceptual \& Motor Skills, 1971, 33, 1219-1222.

WEILER, E. M. (Dept. of Speech \& Hearing, Univ. of Cincinnati, Cincinnati, Ohio 45202), LOEB, M., \& ALLUISI, E. A. Auditory adaptation and its relationship to a model for loudness. Journal of the Acoustical Society of America, $1972,51,638-643$.

WHITMORE, M. G. (Dept. of Admin. Sci., Yale Univ., New Haven, Conn. 06520). Stimulus meaning as a variable in dichotic listening. Psychonomic Science, 1972, 26, 207-208

\section{Auditory Discrimination}

AXELROD, S. (Dept. of Psychiat., State Univ. of New York, Buffalo, N.Y. 14214), \& POWAZEK, M. Dependence of apparent rate of alternating clicks on azimuthal separation between sources. Psychonomic Science, 1972, 26, 217-218.

BARTHOLOMEUS, B. (Sch. of Human Communication Disorders, McGill Univ., Montreal 112, P.Q., Canada). Naming of meaningful nonverbal sounds by blind children. Perceptual \& Motor Skills, 1971, 33, 1289-1290.

DEUTSCH, D. (Ctr. for Human Information Processing, Univ. of California, San Diego, Calif. 92037). Mapping of interactions in the pitch memory store. Science, 1972, 175, 1020-1022.

HOUTSMA, A. J. M. (Ctr. for Communications Sci, Rsch. Lab. of Electronics, M.I.T., Cambridge, Mass. 02139), \& GOLDSTEIN; J. L. The central origin of the pitch of complex tones: Evidence from musical interval recognition. Journal of the Acoustical Society of America, 1972, 51, 520-529.

PASTORE, R. E. (Purdue Univ., Lafayette, Ind. 47907), \& SORKIN, R. D. Simultaneous two-channel signal detection. I. Simple binaural stimuli. Journal of the Acoustical Society of America, 1972, 51, 544-551.

PENNER, M. J. (Univ. of California, San Diego, La Jolla, Calif. 92037).
The effect of payoffs and cue tones on detection of sinusoids of uncertain frequency. Perception \& Psychophysics, 1972, 11, 198-202. P Y N N, C. T. ( Ctr. for Communications Sci., Rsch. Lab. of Electronics, M.I.T., Cambridge, Mass. 02139), BRAIDA, L. D., \& DURLACH, N. I. Intensity perception. III. Resolution in small-range identification. Journal of the Acoustical Society of America, 1972, 51, 559-567.

RAINBOLT, H. (Kansas State Univ., Manhattan, Kans. 66502), \& SMALL, A. M. Mach bands in auditory masking: An attempted replication. Journal of the Acoustical Society of America, $1972,51,567-574$.

STEVENS, S. S. (Lab. of Psychophysics, Harvard Univ., Cambridge, Mass. 02138). Perceived level of noise by Mark VII and decibels $(E)$. Journal of the Acoustical Society of America, $1972,51,575-601$.

TOWNSEND, T. H. (Dept. of Audiology \& Speech Sci., Purdue Univ., Lafayette, Ind. 47907), \& GOLDSTEIN, D. P. Suprathreshold binaural unmasking. Journal of the Acoustical Society of America, 1972, 51, 621-624.

TREISMAN, M. (Univ. of Reading, Reading, England). Detection of binaural tone stimuli: Time sharing or criterion change? Journal of the Acoustical Society of America, 1972, 51, 625-630.

von BÉKÉSY, G. (Lab. of Sensory Sci., Univ. of Hawaii, Honolulu, Hawaii 96822). The missing fundamental and periodicity detection in hearing. Journal of the Acoustical Society of America, 1972, 51, 631-637.

WILLIAMS, K. N. (California State Coll., Los Angeles, Calif. 90032), \& PERROTT, D. R. Temporal resolution of tonal pulses. Journal of the Acoustical Society of America, 1972, 51, 644-647.

\section{Speech Discrimination}

HAMRE, C. E. (Speech \& Hearing Clinic, Northern Michigan Univ., Marquette, Mich. 49855). Stutterers' perception of time-compressed speech. Perceptual \& Motor Skills, 1971, 33, 1031-1034.

MASSARO, D. W. (Univ. of Wisconsin, $\mathrm{M}$ ad is on, Wis. 53706 ). Preperceptual images, processing time, and perceptual units in auditory perception. Psychological Review, 1972, 79, 124-145.

NELSON, D. L. (Univ. of South Florida, Tampa, Fla. 33620), \& DAVIS, M. J. Transfer and false recognitions based on phonetic identities of words. Journal of Experimental Psychology, 1972, 92, 347-353.

\section{LOWER SENSES}

BALL, T. S. (Pacific State Hosp., Pomona, Calif. 91768), \& VOGLER, R. E. Uncertain pain and the pain of uncertainty. Perceptual \& Motor Skills, 1971, 33, 1195-1203.

FUCCI, D. J. (Ohio Univ., Athens, Ohio 45701), HALL, D. E., \& WEINER, F. F. Normative study of oral and non-oral structures using vibrotactile stimuli. Perceptual \& Motor Skills, 1971, 33, $1099-1105$.

GOODWIN, G. M. (Univ. Lab. of Physiol., Oxford OX1 3PT, England), McCLOSKEY, D. I., \& M A T T H E S , P. B . C. Proprioceptive illusions induced by muscle vibration: Contribution by muscle spindles to perception? Science, 1972, 175, 1382-1384.

HASLAM, D. R. (Univ. of Bristol, Bristol, England). Field dependence in relation to pain threshold. British Journal of Psychology, 1972, 63, 85-87.

\section{Chemical Senses}

McBURNEY, D. H. (426 Langley Hall, Univ, of Pittsburgh, Pittsburgh, $\mathrm{Pa}$. 15213). Gustatory cross adaptation between sweet-tasting compounds. Perception \& Psychophysics, 1972, 11, 225-227.

McBURNEY, D. H. (426 Langley Hall, Univ, of Pittsburgh, Pittsburgh, Pa. 15213), SMITH, D. V., \& SHICK, T. R. Gustatory cross adaptation: Sourness and bitterness. Perception \& Psychophysics, 1972, 11, 228-232.

MOSKOWITZ, H. R. (Pioneering Rsch. Lab., U.S. Army Natick Labs., Natick, Mass. 01760). The sweetness and pleasantness of sugars. American Journal of Psychology, 1971, 84, 387-406.

\section{Skin Senses}

BEAUCHAMP, K. L. (Univ, of the Pacific, Stockton, Calif. 95204), MATHESON; D. W., \& SCADDEN, L. A. Effect of stimulus-change method on tactile-image recognition. Perceptual \& Motor Skills, 1971, 33, 1067-1070.

CRAIG, J. C. (Indiana Univ., Bloomington, Ind. 47401). Difference threshold for intensity of tactile stimuli. Perception \& Psychophysics, 1972, 11, 150-152.

WALKER, J. T. (Univ. of Missouri, St. Louis, Mo. 63121). Natural visual capture in bilateral length comparisons. Perception \& Psychophysics, 1972, 11, 247-251. 


\section{PERFORMANCE}

BLACK, R. W. (Univ. of South Carolina, Columbia, S.C. 29208), SCHUMPERT, J., \& WELCH, F. A "partial reinforcement extinction effect" in perceptual-motor performance: Coerced versus volunteer subject populations Journal of Experimental Psychology, 1972, 92, 143-145.

SHOENBERGER, R. W. (Aerospace Med. Rsch. Lab., Wright-Patterson AFB, Ohio 45433). Human response to whole-body vibration. Perceptual \& Motor Skills, 1972, 34, 127-160.

PSYCHOMOTOR TASKS

ADAMS, J. A. (Psychol. Bldg., Univ. of Illinois, Champaign, Ill. 61820), GOETZ, E. T., \& MARSHALL, P. H. Response feedback and motor learning. Journal of Experimental Psychology, 1972, 92, 391-397.

DAVIS, L. J., JR. (Dept. of Psychiat. \& Clin. Psychol., Mayo Clinic, Rochester, Minn. 55901), \& MUENTER, M. D. Psychomotor performances of patients undergoing L-dopa therapy. Perceptual \& Motor Skills, 1971, 33, 1303-1308.

TALKINGTON, L. W. (Fairview Hosp. \& Trng. Ctr., Fairview, Oreg. 97024 ), ALTMAN, R., \& GRINNELL, T. K. Effects of positive and negative feedback on the motor performance of mongoloids. Perceptual \& Motor Skills, 1971, 33, 1075-1078.

\section{Reaction Time}

BLACKMAN, A. R. (Simon Fraser Univ., Burnaby 2, B.C., Canada). Influence of stimulus and response probability on decision and movement latency in a discrete choice reaction task. Journal of Experimental Psychology, 1972, 92, 128-133.

BOTWINICK, J. (Washington Univ., St. Louis, Mo. 63130), \& STORANDT, M. A. Sensation and set in reaction time. Perceptual \& Motor Skills, 1972, 34, 103-106.

COHEN, N. J. (Depts. of Psychol. \& Psychiat., McGill Univ., Montreal, Ont., Canada), DOUGLAS, V. I., \& MORGENSTERN, G. The effect of methylphenidate on attentive behavior and autonomic activity in hy peractive children. Psychopharmacologia (Berlin), 1971, 22, 282-294.

ERIKSEN, C. W. (Univ. of Illinois, Champaign, Ill. 61820), \& HOFFMAN, J. E. Some characteristics of selective attention in visual perception determined by vocal reaction time. Perception \& Psychophysics, 1972, 11, 169-171.
GILINSKY, A. S. (Physiol. Lab., Cambridge CB2 3EG, England), \& COHEN, H. H. Reaction time to change in visual orientation. Perception \& Psychophysics, 1972 11, 129-134.

LAPPIN, J. S. (Vanderbilt Univ., Nashville, Tenn. 37203), \& DISCH, K. The latency operating characteristic: I. Effects of stimulus probability on choice reaction time. Journal of Experimental Psychology, 1972, 92, 419-427.

LOOCKERMAN, W. D. (State Univ. of New York, Buffalo, N.Y. 14214), \& BERGER, R. A. Accuracy of predicting reaction and movement times of a gross motor performance from the dominant hand under simple and choice stimulus conditions. Perceptual \& Motor Skills, 1971, 33, 1326.

PACHELLA, R. G. (Human Performance Ctr., 330 Packard Rd., Ann Arbor, Mich. 48104), \& FISHER, D. Hick's law and the speed-accuracy trade-off in absolute judgment. Journal of Experimental Psychology, 1972, 92, 378-384.

PEEKE, S. C. (Langley Porter Neuropsychiat. Inst., 401 Parnassus Ave., San Francisco, Calif. 94122), \& STONE, G. C. Sequential effects in two- and four-choice tasks. Journal of Experimental Psychology, 1972, 92, 111-116.

PORGES, S. W. (West Virginia Univ., Morgantown, W. Va. 26506). Heart rate variability and deceleration as indexes of reaction time. Journal of Experimental Psychology, 1972, 92, 103-110.

SIMON, J. R. (Univ. of lowa, Iowa City. Iowa 52240), \& CRAFT, J. L. Reaction time in an oddity task: Responding to the "different" element of a three-light display. Journal of Experimental Psychology, 1972, 92, 405-411.

THEIOS, J. (Univ. of Wisconsin, Madison, Wis. 53706), \& SMITH, P. G. Can a two-state model account for two-choice reaction-time data? Psychological Review, 1972, 79, 172-177.

\section{Laterality}

BRUML, H. (Northern Virginia Mental Health Inst., 3302 Gallows Rd., Falls Church, Va. 22046). Age changes in preference and skill measures of handedness. Perceptual \& Motor Skills, 1972, 34, 3-14.

COHEN, G. (Inst. of Exper. Psychol., 1 S. Parks Rd., Oxford, England). Hemispheric differences in a letter classification task. Perception \& Psychophysics, 1972, 11, 139-142. DIMOND, S. J. (University Coll.,
Cardiff, Wales), \& BEAUMONT, J. G. A right hemisphere basis for calculation in the human brain. Psychonomic Science, 1972, 26, 137-138.

PARSONS, O. A. (Univ. of Oklahoma Med. Ctr., Norman, Okla. 73069), JONES, B., \& VEGA, A. Halstead's category test and lateralized brain damage. Perceptual \& Motor Skills, $1971,33,1245-1246$.

\section{ATTENTION}

COLLINS, D. (Yale Univ., New Haven, Conn. 06520), KESSEN, W., \& HAITH, M. Note on an attempt to replicate a relation between stimulus unpredictability and infant attention. Journal of Experimental Child Psychology, 1972, 13, 1-8.

ELY, D. J. (Porterville State Hosp., Porterville, Calif. 93257). Temporal duration as a dimension in generalization of the orienting response. Perceptual \& Motor Skills, $1972,34,271-276$

ERIKSEN, C. W. (Univ. of Illinois, Champaign, Ill. 61820), \& HOFFMAN, J. E. Some characteristics of selective attention in visual perception determined by vocal reaction time. Perception \& Psychophysics, 1972, 11, 169-171. GLOBUS, G. G. (Dept. of Psychiat. \& Human Behav., Univ. of California, Irvine, 101 S. Manchester Ave., Orange, Calif. 92668), DRURY, R. L., PHOEBUS, E. C., \& BOYD, R. Ultradian rhythms in human performance. Perceptual \& Motor Skills, 1971, 33, 1171-1174.

WARM, J. S. (Univ. of Cincinnati, Cincinnati, Ohio 45221), KANFER, F. H., KUWADA, S., \& CLARK, J. L. Motivation in vigilance: Effects of self-evaluation and experimenter-controlled feedback. Journal of Experimental Psychology, 1972, 92, 123-127.

INFORMATION PROCESSING

BARTZ, W. H. (Iowa State Univ., Ames, Iowa 50010). Repetition effects in dichotic presentation. Journal of Experimental Psychology, 1972, 92, 220-224.

GRAHAM, N. (Rockefeller Univ., New York, N.Y. 10021). Spatial frequency channels in the human visual system: Effects of luminance and pattern drift rate. Vision Research, 1972, 12, 53-68.

GUMMERMAN, K. (Mezes Hall 211, Univ. of Texas, Austin, Tex. 78712), \& GRAY, C. R. Age, iconic storage, and visual information processing. Journal of Experimental Child Psychology, 1972, 13, 165-170.

KANTOWITZ, B. H. (Purdue Univ., Lafayette, Ind. 47907), \& SANDERS, M. S. Partial advance 
information and stimulus dimensionality. Journal of Experimental Psychology, 1972, 92 , 412-418.

LEEUWENBERG, E. L. J. (Univ. of Nijmegen, The Netherlands). A perceptual coding language for visual and auditory patterns. American Journal of Psychology, $1971,84,307-350$.

MATTHEWS, L. (Idaho State Univ., Pocatello, Idaho 83201). Subject-determined postfeedback interval in auditory concept identification. Psychonomic Science, 1972, 26, 193-194.

MILLER, L. K. (Univ. of Illinois, Chicago Circle, Chicago, ill. 60680). Letter recognition: Effects of interitem similarity and report requirements. Perception \& Psychophysics, $1972,11,252-256$.

PARKS, T. E. (Univ. of California, Davis, Calif. 95616), KROLL, N. E. A., SALZBERG, P. M., \& PARKINSON, S. R. Persistence of visual memory as indicated by decision time in a matching task. Journal of Experimental Psychology, 1972, 92, 437-438.

RANDHAWA, B. S. (Univ. of Saskatchewan, Saskatoon, Canada). Nonverbal information storage in children and developmental information processing channel capacity. Journal of Experimental Child Psychology, 1972, 13, 58-70.

ROLLINS, H. (Emory Univ., Atlanta, Ga. 30322), EVERSON, M., \& SCHURMAN, D. L. Preferred recall order and recall accuracy for two messages presented simultaneously over a single auditory channel. Perception \& Psychophysics, 1972, $11,153-155$.

SHAFFER, W. O., \& SHIFFRIN, R. M. (Indiana Univ., Bloomington, Ind. 47401). Rehearsal and storage of visual information. Journal of Experimental Psychology, 1972, 92, 292-296.

SHANTEAU, J. (Kansas State Univ., Manhattan, Kans. 66502), \& ANDERSON, N. H. Integration theory applied to judgments of the value of information. Journal of Experimental Psychology, 1972, 92, 266-275.

\section{SLEEP \& FATIGUE}

CHERNIK, D. A. (Univ. of Pennsylvania, Philadelphia, $\mathrm{Pa}$. 19104). Effect of REM sleep deprivation on learning and recall by humans. Perceptual \& Motor Skills, 1972, 34, 283-294.
CLIFTON, R. (Univ. of Massachusetts, A mherst, Mass. 01002 ), SIQUELAND, E. R., \& LIPSITT, L. $P$. Conditioned headturning in human newborns as a function of conditioned response requirements and states of wakefulness. Journal of Experimental Child Psychology, $1972,13,43-57$.

DUNLEAVY, D. L. F. (Dept. of Psychiat., Univ. of Edinburgh, Royal Edinburgh Hosp., Edinburgh
EH10 5HF, Scotland), MacLEAN, A. W., \& OSWALD, I. Debrisoquine, guanethidine, propranolol and human sleep. Psychopharmacologia (Berlin ), 1971, 21, 101-110.

FISCHER, W. (Universität Bielefeld, Bielefeld, W. Germany), \& MICKO, H. C. More about metrics of subjective spaces and attention distributions. Journal of Mathematical Psychology, 1972, 9, 36-54.

\section{SOCIAL PROCESSES}

BRICKMAN, P. (Northwestern Univ., Evanston, Ill. 60201), REDFIELD, J., HARRISON, A. A., \& CRANDALL, R. Drive and predisposition as factors in the attitudinal effects of mere exposure. Journal of Experimental Social Psychology, 1972, 8, 31-44

FRY, A. M., \& WILLIS, F. N. (Univ. of Missouri, Kansas City, Mo. 64110). Invasion of personal space as a function of the age of the invader. Psychological Record, 1971, 21, 385-389.

GRANBERG, D. (Dept. of Sociol., Univ, of Missouri, Columbia, Mo. 65201 ). Adaptation of psychophysical and psychosocial judgments to shifts in stimuli. Journal of General Psychology, 1972, 86, 85-92.

GUTTENTAG, M. (Grad. Ctr., CUNY, New York, N.Y. 10036), \& WHEELER, G. Group effects on individual inferences. Perceptual \& Motor Skills, 1972, 34, 15-25.

HEWITT, J. (Univ. of Missouri, Kansas City, Mo. 64110). Similarity vs social desirability as determinants of attraction. Psychonomic Science, 1972, 26, 219-221.

LIVINGSTON, J. W., JR. (Rutgers Univ., New Brunswick, N.J. 08903). Measuring cooperation and competition in decomposed games. Behavior Research Methods \& Instrumentation, 1972, 4, 113-114. MILLER, A. G. (Miami Univ., Oxford, Ohio 45056). Effect of attitude similarity-dissimilarity on the utilization of additional stimulus inputs in judgments of interpersonal attraction. Psychonomic Science, $1972,26,199-203$

NATALICIO, L. F. S. (Sch. of Ed., Univ. of Texas, El Paso, Tex. 79999), \& KIDD, R. V. A conceptual shift: An operant approach to human interaction. Psychological Record, 1971, 21, 521-526.

NORMAN, R. Z. (Dartmouth Coll., Hanover, N.H. 03755), \& ROBERTS, F. S. A derivation of a measure of relative balance for social structures and a characterization of extensive ratio systems. Journal of Mathematical Psychology, 1972, 9, 66-91.

O'NEAL, E. (Tulane Univ., New Orleans, La. 70118), \& KAUFMAN, $\mathrm{L}$. The influence of attack, arousal, and information about one's arousal upon interpersonal aggression. Psychonomic Science, 1972, 26, 211-214.

SCHUTZ, S. R. (Gordon Coll., Wenham, Mass. 01984), \& KEISLAR, E. R. Young children's immediate memory of word classes in relation to social class. Journal of Verbal Learning \& Verbal Behavior, $1972,11,13-17$.

STEWART, C. G. (Tulane Univ., New Orleans, La. 70118). Consistency, generality, magnitude, and significance of experimenter expectancy effects in human research. Psychological Record, 1971, 21, 449-458.

VANTRESS, F. E. (Univ. of Manitoba, Winnipeg, Man., Canada), \& WILLIAMS, C. B. The effect of the presence of the provocator and the opportunity to counteraggress on systolic blood pressure. Journal of General Psychology, 1972, 86, 63-68.

ZAJONC, R. B. (Univ. of Michigan, Ann Arbor, Mich. 48104), WOLOSIN, R. J., \& WOLOSIN, M. A. Group risk-taking under various group decision schemes. Journal of Experimental Social Psychology, $1972,8,16-30$. 